[Please note this is a pre-publication version (post peer review) of an article published in the Journal of Contemporary Archaeology. Full citation:

\author{
Sterling, C. "A Thing is its Own Best Mask": Antagonisms of the Architectural Wrap. \\ Journal of Contemporary Archaeology 4.1, 91-106]
}

\title{
'A Thing is its Own Best Mask:' Antagonisms of the Architectural Wrap
}

Beware of saying to them [the traveller] that sometimes different cities follow one another on the same site and under the same name, born and dying without knowing one another, without communication among themselves. At times even the names of the inhabitants remain the same, and their voices' accent, and also the features of the faces; but the gods who live beneath the names and above places have gone off without a word (Calvino 1997 [1972], 31).

This photo-essay considers a recent and increasingly widespread manifestation of the heritage phenomenon; namely, the act of wrapping a building in an image of itself during conservation, rebuilding, or restoration work. New visualising and printing technologies have made these often vast wraps possible, and they are now routinely deployed in towns and cities across the world. In recent years I have encountered wrapped buildings in Paris, Manchester, Amsterdam, New York, and St. Petersburg. The use of the wrap is not limited to urban contexts, however, with large-scale historic properties such as Cliveden House (Figures 1 and 2) also undergoing a process of visual enfolding to conceal and promote conservation work. The prevalence of London in the current set of images responds to the pervasiveness of this practice in a city with which I am acutely familiar. The key question here is: what are we to make of such impactful yet puzzling spectacles, and how can the additional visual-discursive layer of the photograph help us to interrogate the wrap's peculiar qualities and reverberations?

\section{[FIGURES 1 and 2 HERE]}

Perhaps the best known example of a wrapped building is also one of the most atypical. In 1995, the artists Christo and Jeanne-Claude enveloped the Reichstag in over one million square feet of polypropylene fabric. Their stated aim? To reveal the 'essence' of the building (Christo in Glancey 1995). Seeking to accentuate the hidden form of the structure, the fragile and fluid materiality of the veil drew attention through concealment, exposing through erasure. In the process, an enduring edifice laden with history was made to seem transient, as if it might float away on the next breeze.

Such a monumental example of architectural effacement is unusual for a number of reasons. Audacious and spectacular, Christo and Jeanne-Claude's artwork transformed not just the appearance of the Reichstag, but its role in the life of the city. From afar, the building resembled nothing so much as a giant bouncy castle, while up close the folds and pleats of the fabric invited a very different tactile engagement with the structure than would normally be enacted. Although the project took over two decades to realise, the wrap remained in place for just 14 days. This temporary metamorphosis did not give birth to a restored structure, but rather sought to provoke a renewed perception of the building within. As one journalist wrote at the time, if the architecture of the Reichstag represents a kind of Prussian hardness - Germany as it was - the wrapped version can almost be seen as an ideal symbol of the new Germany' (Mundy 2012). For the artists, a key 
component of this new vision was the undermining of any sense of immortality or permanence as residing in works of art, or indeed historic buildings. The wrap would create a 'tremendous intensity,' they argued, its brevity evoking the transience of life itself (ibid).

In many ways the building wraps I am interested in here work in the opposite direction. Where Christo and Jeanne-Claude's sculptural mediation sought to amplify the Reichstag's distinctive physicality by abstracting the form, and thus the essence, of the building, the wraps now commonly used during restoration or renovation projects copy and display a distinctly flattened version of the sites they shelter. Notably, such wraps are deployed in urban areas where a desire to conserve is met with the commercial pressures of development. Like the related practice of facadism (Richards 1994), the building wrap is called upon to promote and preserve some sense of visual continuity while wholesale change is wrought to a site. Walls may be torn down, interiors ripped apart, elevations rebuilt - all under the serene mask of an image of how that building used to be, or how it might look when work is completed. Far from disclosing the essence of the structure beneath, then, this practice evokes a more complex range of issues related to the role of heritage in the contemporary city. These relate both to the building itself and to the wider preservationist approaches the method of wrapping a building ties into.

The process of creating an architectural wrap can take several forms. A building may be photographed, recreated using imaging software, or represented through more creative means (e.g. illustration, painting). Most commonly, the resulting image is then printed onto a durable polyester based material using a super wide format printer. The prints are then welded together into panels or strips before they are attached to the scaffold, the aim being both to protect construction workers from the elements and conceal their activities. As one promotional site suggests, 'the printed building wrap will help the community by reducing dust, hiding the workforce and unsightly scaffolding structure. By keeping the building site as smart and tidy as possible it will demonstrate to the community you care about how the building work will affect them' (Murray 2013).

The wraps resulting from this process are part of a material-visual shift in the way we encounter and engage with the structures beneath. This works at two different levels. First, the wrap effectively cocoons the building, displacing and plasticising its more rigid substances while conservation or reconstruction work is undertaken. This however could be said of any type of enclosure, and so it is the second, visual, shift that we must turn to for the operative impact of the wrap; an impact that paradoxically seeks to divert from the wrap's very presence. The argument here of course is not that such disguises are so realistic they achieve this goal, but that in reaching for this sense of visual stability they expose the work of preservation and heritage in the modern city to a peculiar type of unfocused scrutiny. Bendy bricks, static shadows, blurry concrete and floating foliage all betray the overwhelming imageness of the wrap. At this site on Bishopsgate for example (Figures 3 and 4) the fuzzy detailing of the wrap, stretched across the scaffold, makes clear a shift in the materiality of the building. Despite appearances, the photograph here is not out of focus - the building itself is. On Portland Place meanwhile the false windows of the partially wrapped Langham Hotel reflect buildings that are nowhere to be seen, the result of a single image from an opposing façade being repeated across the scaffold (Figures 5 and 6). The absence of fidelity in these image-wraps creates a strangely pixelated streetscape, out of sync with the surrounding urban environment.

\section{[FIGURES 3, 4, 5 and 6 HERE]}

This sense of obfuscation and misdirection is not inevitable. Indeed, from one perspective the notion of framing and announcement sanctioned by the wrap can be considered a welcome 
invitation to consider the activity and decision-making processes that go into heritage practice. As artist-architect Jorge Otero-Pailos has recently argued, preservation - at a very basic level - is 'the organisation of attention [...] it's about telling you what to look at and what to value as important. It's about putting a frame on the world' (2016). By enclosing the work of architectural conservation in such a visible way the building wrap raises awareness of itself, highlighting the thing to be saved (at least superficially). For this organisation of attention to be made more meaningful however it must also question what is happening beneath: the retention of facades; the comprehensive destruction of historic interiors; the shift in the use and value of the building. The wrap effectively elides these issues, offering up a simplified framing of the material past for visual consumption or - more likely - total disregard by the passer-by. At one level my photographic documentation of these wraps attempts to undo the oblivion they seek for themselves, but in so doing a further set of associations and consequences is brought to the fore, focused on the concepts of abstraction and masking that the wraps so clearly evoke.

To explore these ideas further we need to attend to the foreclosures and contradictions of the wrap, qualities which are both written into the surface of the practice and obscured by its deceptions. This paradoxical or even antagonistic reading resonates with the work of Slavoj Žižek, who often returns to a 'structure of antinomies' as his philosophical starting point (Roth 2012: xiii). In Žižek's work the 'Real' can only ever be observed obliquely, through the shifts that occur between the noumenal - the thing itself - and the phenomenal (and back again). The antinomy of these two points is never to be resolved or 'worked through' (ibid), thus revealing a constant gap, which Žižek labels the parallax.

For Žižek, the term parallax defines a 'strategic politico-philosophical decision' designating that which 'separates the One from itself' $(2006,7)$. There is no synthesis possible between 'the One' and itself in Žižek's philosophy, because the constantly shifting perspectives of two points disallows 'neutral common ground' (ibid, 4). The parallax is thus marked by dislocation, displacement, and, ultimately, an eternal 'noncoincidence' (ibid, 7). This is useful for our understanding of the wrap from a number of angles. First, the notion of the parallax resonates with the physical separation of the wrap from the building it purports to represent. The wrap opens a highly visible material-discursive gap between architecture and its image, thus allowing for a critical vantage point to be taken on the thing itself, which - crucially - is not simply the enclosed building. Second, and related to this, the wrap speaks to an incommensurability between outside and inside. This is central to Žižek's conceptualisation of the parallax, which addresses the fact that 'in our most elementary phenomenological experience, the reality we see through a window is always minimally spectral, not as fully real as the closed space where we are' (Žižek 2009). In other words, the wrap and the parallax both confront a sense of detached apprehension, drawing out the shifting valences of 'the real' as observed, felt, or experienced. Finally, but perhaps most importantly, the parallax asks us to acknowledge the impossibility of closure, highlighting instead the ongoing tensions and antagonisms that structure the world. For Žižek, these tensions mean that reality can never be seized directly, it is always 'curiously provisional' and marked by 'asymmetrical resolution' (ibid). As such, 'we can only grab reality through the failure of the structures that attempt to get at it [...] their truth is in the way they miss reality' (The Žižek Times 2017). The everyday surrealism of the wrap is an evocative demonstration of this idea, but what then is the truth that the wrap reveals, and how might the productive tensions of the wrap be articulated through photography?

\section{[FIGURES 7 and 8 HERE]}

As highlighted by Žižek in various contexts, the figure of the mask is crucial to addressing these questions. Again and again when discussing the notion of the parallax Žižek returns to the story 
of the Argentinian Minister of the Economy Domingo Cavallo, who, in 2001 escaped through an angry crowd of protestors gathered around his building by wearing a mask of himself, sold in disguise shops so that people could mock him. 'It thus seems,' Žižek explains with typical irony, 'that at least Cavallo did learn something from the widely spread Lacanian movement in Argentina-the fact that a thing is its own best mask' (2005, my emphasis). The conclusion Žižek takes from this comical episode further resonates with the wraps I am interested in here: 'when, instead of a hidden terrifying secret, we encounter behind the veil the same thing as in front of it, this very lack of difference between the two elements confronts us with the "pure" difference that separates an element from itself (2005, emphasis in original).

How can an element be separated from itself, and what does it mean to think through the building wrap in these terms? At one level, the connections between Cavallo's comedic act of escapology and the curious practice of wrapping a building in its own image are obvious. In both, an element is replicated, and this copy is used to conceal the original. This repetition seeks to distract from the thing itself by projecting a reified version of the object beneath. Moreover, in the case of both Cavallo and the building wraps I document here, there is a sense that the thing hidden is in some ways abject. For the Argentinian Minister this is related to his own unpopularity, but for the architectural wrap it is a sign that the building site, with all its noise and dust and confusion, should be kept from view. In this way the wrap not only separates the thing from itself, it also masks the processes through which the thing is in fact transformed. There is a stark and telling difference here, however, for while Cavallo's mask sought to deny the thing within, and therefore mislead the angry crowd, the building wrap openly welcomes contemplation of the thing as was and crucially - will be. Of course, what it emphatically does not show is the process of change and the metamorphosis of the thing. The difference between before and after is elided by the wrap, which simultaneously announces and bestills the material transformation underneath. To borrow from Calvino, while the street may look the same, the gods who live beneath have gone off without a word.

To see this another way, we might suggest that if a thing is to be its own best mask, there has to be a perception of difference between the thing and the mask. This raises an interesting conundrum for the architectural wrap, which is sold on the belief that there is no difference between it and the building beneath. Some wraps take this to an extreme degree. In the upmarket streets of Kensington and Chelsea, for example, the remarkable accuracy of one wrap can be seen to have duplicated open French windows and forever stilled a momentary reflection of clouds and trees (Figure 9). On Hanover Square and Regent Street meanwhile two opposing approaches are taken. In the first, any blemishes have been removed from the image-wrap (Figures 10 and 11). The building appears as pure surface, accentuated by the motionless shadows that give a semblance of depth. By way of contrast, at Regent Street the imperfections of the building beneath have been retained in the wrap, with broken windows and chipped masonry clearly visible (Figures 12 and 13). Such repetitions paradoxically extend the life of the dilapidated structure, acting almost like a death mask in remembrance of the building that was. At this level, the sense of separation communicated by the wrap appears to commemorate those very processes of dislocation and transformation contained in the act of preserving. The wrap becomes then an emblem of fractured memory, of things broken and shattered yet ostensibly uninterrupted: a discontinuous continuity.

\section{[FIGURES 9, 10, 11, 12 and 13 HERE]}

Such differential approaches remind us that the role of the wrap as mask is about more than simply covering the thing inside. As Žižek (following Frederic Jameson) suggests in a discussion of the symmetrical yet oblique facial decorations used by the Caduveo people of Brazil, there can be an opposition between the 'ideal axis of the object itself [...] and the ideal axis of the figure which it 
represents' (Jameson in Žižek 2009). The contradictions of the mask are here interpreted as a 'transposition-displacement of the basic social imbalance-asymmetry-antagonism of Caduveo society' (Žižek after Claude Levi-Strauss 2009). With characteristic flair Žižek goes on to connect this mode of masking to postmodern architecture, where a 'conflict of principles' is often inscribed into the hybridised form of buildings (Žižek 2009). However, if the Caduveo masks allow for an indirect apprehension of antagonistic structures, the open display of the parallax in postmodernism means its subversive edge is lost. The historical, aesthetic and functional contradictions of the postmodern are shown to neutralise the productive tensions of the parallax, giving rise to an 'indifferent plurality of standpoints' (ibid). The upshot here is the cynical reaction 'So What?' 'Sometimes, the thing itself can serve as its own mask - the most efficient way to obfuscate social antagonisms is to openly display them' (ibid).

In many ways the architectural wrap can be seen to endorse just this kind of display. It invites the observer to look at the work of conservation or restoration, but then distracts them with a static mask. The stillness of the wrap evokes continuity, while its very presence speaks to disruption and change. In certain contexts - King's Cross for example (Figures 14-17) - this false serenity gestures towards more troubling societal developments. Here, the rampant gentrification of an area gains an iconic heritage symbol, announced by the presence of the wrap. Such open displays of architectural and social transformation are seen in towns and cities across the world. While it is tempting to dismiss these practices as superficial and spectacular, there is a need to overcome the initial obfuscation enacted through and by the wrap. This is not about getting at the 'truth' of the building beneath, but rather at the complexities of the social antagonisms structuring heritage and its role in the world. The failures of the wrap - shown here in the form of pixelated glitches, erratic reflections, and material inconsistencies - provide one route into the realities missed by the wrap. To return to Žižek's formulation, it is precisely these malfunctions that allow for 'productive thinking,' perpetuating 'the tension and the incommensurability [of the parallax] rather than palliating or concealing it' (Jameson 2006). Here, the added visual-discursive layer of the photoessay acts like an $\mathrm{x}$-ray, becoming both a record of the moment of wrapping and a conduit for its subjective-epistemological displacement. Such processes create a dense sedimentation of materiality and image that is of particular value to the contemporary archaeologist. A focus on appearance and the management of attention thus gives way to a deeper engagement with the efficacies of the past in the present, which must be our starting point for a renewed critical enquiry into the heritage phenomenon.

\section{[FIGURES 14, 15, 16 and 17 HERE]}

\section{Postscript}

I often wonder what happens to the building wrap when construction or conservation work is completed. Most likely they are recycled, but I like to imagine there is a town somewhere - less substantial even than those built by Hollywood in the golden age of the Western - where street upon street is made up of the world's abandoned façades, fluttering gracefully on their trusty scaffolds. 


\section{References}

Calvino, I. 1997 [1972]. Invisible Cities. Translated by William Weaver. London: Vintage

Glancey, J. 1995. It's a Wrap. The Independent 16 June. Available online:

http://www.independent.co.uk/arts-entertainment/its-a-wrap-1586760.html [last accessed 17 November 2016]

Jameson, F. 2006. First Impressions (Review of The Parallax View). London Review of Books March. Available online: http://www.lrb.co.uk/v28/n17/fredric-jameson/first-impressions [last accessed 17 November 2016]

Mundy, J. 2012. Lost Art: Christo and Jeanne-Claude. Tate 12 November. Available online: http://www.tate.org.uk/context-comment/articles/gallery-lost-art-christo-jeanne-claude [last accessed 17 November 2016]

Murray, J. 2013. Cost of digitally printed building wrap on mesh banner. Wide Format World. August 7 2013. Available online: http://www.wideformatworld.com/profiles/blogs/cost-ofdigitally-printed-building-wrap-on-mesh-banner [last accessed 17 November 2016]

Otero-Pailos, J. 2016. Ritual Evidence. Architect Magazine March 7. Available online: http://www.architectmagazine.com/aia-architect/aiafeature/ritual-evidence_o [last accessed 18 November 2016]

Richards, J. 1994. Facadism. London: Routledge

Roth, M. S. 2012. Memory, Trauma, and History: Essays on Living with the Past. New York: Columbia University Press

The Žižek Times. 2017. Duel + Duet: Slavoj Žižek and Graham Harman at SCI-Arc on March 2, 2017. https://www.youtube.com/watch?v=OhMycybHkuI\&t=6976s [last accessed 7 April 2017]

Žižek, S. 2005. The Christian-Hegelian Comedy. Cabinet 17 (Spring). Available online: http://www.cabinetmagazine.org/issues/17/zizek.php [last accessed 18 November 2016]

Žižek, S. 2006. The Parallax View. London \& Cambridge, Mass: The MIT Press

Žižek, S. 2009. Architectural Parallax: Spandrels and Other Phenomena of Class Struggle. Lacan Dot Com. Available Online: http://www.lacan.com/essays/?page_id=218 [last accessed 7 April 2017] 


\section{Figures}

Figure 1. Cliveden House 1

Figure 2. Cliveden House 2

Figure 3. Bishopsgate 1

Figure 4. Bishopsgate 2

Figure 5. Portland Place 1

Figure 6. Portland Place 2

Figure 7. Cambridge Circus

Figure 8. Covent Garden

Figure 9. Sloane Street

Figure 10. Hanover Square 1

Figure 11. Hanover Square 2

Figure 12. Regent Street 1

Figure 13. Regent Street 2

Figure 14. King's Cross 1

Figure 15. King's Cross 2

Figure 16. King's Cross 3

Figure 17. King's Cross 4 